\title{
Patterns, Trends and Policy Processes in Spanish Secondary Education: Multiple Streams in a Multilevel Context
}

\author{
Eliseo López Sánchez \\ Facultad de CCPP y Sociología Universidad Complutense de Madrid \\ eliseorl@cps.ucm.es
}

Esther del Campo

Instituto Complutense de Estudios Internacionales of

Universidad Complutense de Madrid

delcampo@cps.ucm.es

\section{ABSTRACT}

Educational policies in Spain have been characterized by conflict and continuous changes to legislation in the Central State. However, Spain is a decentralized State and the Autonomous Communities (regions) are responsible for implementing secondary education. The article aims at explaining and analyzing how Autonomous Communities have defined their educational models and policies for secondary education based on an unstable state legal framework. The analysis focuses on key elements of State legislation, such as the management methods of schools and the adaptation of policies to social differences between autonomous communities. Based on Zahariadis' multiple streams model, the article concludes by pointing out the importance of the context and its impact on the policies, the relevance of the ruling party's ideology in each Autonomous Community and the involvement of stakeholders in the implementation of secondary education policy.

Key words: educational system, public secondary education, direct management, outsourcing, autonomous jurisdictions, multilevel government, Spain

JEL: $128, K 39$

\section{Introduction}

This article presents the first findings, not yet systematic, of an ongoing research project which aims at identifying and analyzing how the Spanish Autonomous Communities (ACs) - in three cases: the Basque Country, Andalusia and Madrid - use their decision power as a result of public policy choices made by their political leaders. The research in secondary education policy is based on personal interviews with policy-makers and with many social stakeholders from the three ACs and the Central State. In addition, literature on 
public secondary education in Spain, legal texts and the review of the ACs' press have been taken into consideration.

Regarding the State legislative framework, the Organic Law on Education (LOE) of 2006, currently in force ${ }^{1}$, consolidated the Autonomous jurisdictions and represented an opportunity for regions to develop or consolidate their educational models themselves.

Within these models, the Basque Country, Andalusia and the Region of Madrid can be considered extreme, and serve as role models for other Spanish ACs.

Thus, the questions that guide our study are the following: Why have they been defined as different models if the State's general framework is the same? What criteria do they follow to set their policies? Do they adapt to the different circumstances of each Autonomous Community? Do they include stakeholders in the processes to define problems and goals? Finally, each model is analyzed to see to what extent education is considered a public service, a constitutional right, a tool to create a collective identity, whether it is conceived as a system for job market training, etc.

To approach this study, we have selected the perspective of multiple streams or windows of opportunity as our theoretical framework, which was developed by Kingdon (1984) and later taken up by Zahariadis (1999, 2003, 2007). We consider that this approach is particularly relevant for two reasons: firstly, due to the fact that ideas are given an important role (political paradigms, belief systems and policy images) and these are successfully disseminated as a means to explain the changing expectations of political stakeholders or coalition members, as well as to promote a change in policy and, secondly, because, the policy subsystem is assumed as the main unit of analysis.

Briefly, this approach identifies three streams - problem stream, policy stream and political stream ${ }^{2}$ - which can couple at a specific point in time to generate windows of opportunity that allow political entrepreneurs to appropriately include topics they promote or advocate for in the government's agenda ${ }^{3}$. Although this framework has been used in the past to explain the development of higher education (Maguire, 2008), it is the first time it has been used for Spanish secondary education.

Firstly, we present the initial situation of these educational policies within the scope of the Central State, as such scope has marked the key lines of political

1 In 2013 the 7th Law on Education was passed since the beginning of Spanish democracy, the Organic Law for the Improvement of the Quality of Education (LOMCE).

2 Problem streams are the circumstances that policy-makers and people are willing to address; such as environmental problems, transportation, health care or, in our case, education. Policy streams are all the ideas that compete to receive attention. Political streams consist of three elements: the national mood, lobby campaigns, and administrative or legislative changes.

3 Policy windows are defined as fleeting opportunities for advocates of proposals to push their pet solutions, or to draw attention to their social problems. When policy windows open, policy entrepreneurs must immediately seize the opportunity to initiate action. 
confrontation, and jurisdiction over secondary education has been transferred from this level to ACs at different times. The article is then structured into four sections and the conclusions. The first section overviews the Spanish educational system, indicating both the legal changes and the institutional inertia that have taken place within this period. The other sections focus on the analysis of the three regional models under research.

\section{Evolution, Changes and Institutional Inertias of the Legal Framework in Spanish Education}

Secondary education policies in Spain are under regional jurisdiction at the implementation level, and the general legal framework falls under the powers of the Central State. This jurisdiction has been transferred to the different ACs at different periods.

Several organic laws ${ }^{4}$ have defined a set of common elements to all ACs since the 1980s, while other elements have been open to the autonomous decision of regional political bodies.

Among the issues that the Central State decides on are:

- Percentage of the courses and their contents.

- System for student promotion.

- Types of educational centers according to their management method: direct public management, outsourced (privately managed by agreement with the public sector) and private.

- Criteria for teacher recruitment.

In this general model, the successive laws have left some room for ACs to decide on, which has allowed them to outline different educational models. We can also identify several key issues that regional politicians have had to define:

- Percentage of elective courses and their contents.

- Management of secondary schools (high schools), including direct management and outsourced management. Regional authorities sign outsourcing agreements and conditions according to rules set by the Central State.

- Recruitment of teachers in the public sector, as well as of regional educational administrative staff.

- Criteria for selection of students applying for admission to secondary schools.

4 An Organic Law is a framework law that only the Central State can pass and needs to be approved by an absolute majority in the two chambers of the Spanish Parliament. 
However, the evolution of each model is different, based on two main elements. First, the socio-economic differences which affect the problem streams of ACs policies. Second, the political environment of the Central Government, which affects the political stream and has been characterized by uncertainty and changes in a selected part of the model. In fact, a new change is being implemented at the moment.

The changes to the Spanish educational framework have occurred every time there has been a change in the Central State's parliamentary majority between the two main Spanish political parties, PP (conservative) and PSOE (social-democratic). It should also be noted that the previous reference point was the 1970 Law, passed in the last period of Franco's dictatorship, which consolidated the provision of universal primary education, however using two types of schools: public and private ${ }^{5}$.

The public high schools were managed in a hierarchical, bureaucratic and centralized manner, and reported to a ministerial structure that was present in the entire Spanish territory through provincial departments, yet their decision-making autonomy was quite limited. Alongside the public high schools there were multiple private centers, mostly owned and managed by Catholic Orders, although there were also secular private high schools which were owned by individuals or cooperatives. The distribution in the territory of these schools was uneven, with significant differences between the provinces. In general terms, it could be argued that private centers were concentrated in urban areas, and in Northern Spain rather than in the South.

Once the current Constitution of 1978 entered into force, the Government headed by Adolfo Suarez aimed to adapt the Spanish educational system to the new political regime. The Parliament passed the Organic Law Governing the Statute of Schools (LOECE). This 1980 Law gave rise to a strong confrontation with PSOE, the main opposition party at that time. The lack of agreement forced PSOE to take the law to the Constitutional Court, which published its judgment in 1981, invalidating many of its provisions. The Law never came into force.

The next milestone occurred in 1985, with Felipe González's Government (1982-1996): the Organic Law on the Right to Education (LODE). It meant a reorganization affecting all educational centers and their management. The most important aspects of this Law on the management of schools are:

- All public high schools should have a School Council, composed of the representatives of parents' associations (AMPAS), students and faculty. High school faculty would elect school principals, selecting one among them.

\footnotetext{
5 For more specific information on the dualization process between public and private education in the Spanish educational system as well as on its impact on educational inequalities see Bonal (2002).
} 
- Many private schools, not all, were integrated into the public educational system, through service agreements, which meant outsourcing the supply and management of a public service.

In practice, the implementation of the legal rules, the budget allocation and control was in the hands of the Ministry of Education, so the management of public schools was not decentralized. In fact, the School Councils could not choose an educational project for their center under LODE - for instance, the teaching method, or content and course specialization were decided by the Ministry.

Private schools which signed an agreement with the Ministry of Education, or with the relevant Regional Government Department if educational powers had been transferred, took on course contents and students who resided in the area assigned by the Ministry, or by the Regional Department, and who applied for studying at these Private Schools. Outsourced schools could also shape their School Councils, although their role was truly limited.

Regarding personnel selection, public schools should recruit their teachers through the model for civil service in force, a career model which is the basic model in all Spanish public administrations. Private schools could recruit their teachers from those who met some academic degree requirements and passed a nation-wide aptitude test, which applied to non-outsourced private schools anyway. In the case of secondary education, teachers had to be graduates of areas related to the courses they taught, both in public and in private schools.

The fundamental problem that LODE tried to solve in 1985 was the overcrowding of the network of public high schools, as children born from the mid-1960s to the mid-1970s - a period when Spanish birth rate had grown - reached school age at that time. Spanish birth rate had dropped since then, so the alternative of building new schools under direct management was dismissed, as they would have no students by the end of the 20th century.

In 1990 another controversial Law was enacted to complement the above - the Organic Law on the General Organization of the Educational System (LOGSE). This Law mainly changed the courses and their contents, while the dual network of high schools remained intact. However, LOGSE stipulated that principals would be elected by School Councils.

LOGSE introduced some improvements, such as a maximum of 30 students per classroom, psychological counselors and support teachers for students with difficulties in each high school, it raised the age for compulsory education from 14 to 16 years and the education inspectorate was given a greater role. It also strengthened the agreements with private schools, but as a right of parents to choose their children's education, and not as a short-term solution to the problem of temporary excess of demand. 
With the change in parliamentary majority in 1996 and the start of José María Aznar's mandate, the implementation of LOGSE was constantly challenged. However, PP did not have an absolute majority in the Spanish Parliament then, and did not get sufficient support to amend this framework law. When PP got an absolute majority in 2000, Aznar's Government promoted the Organic Law on Education Quality (LOCE), enacted in 2002. This Law gave rise to great controversy about the role of Catholic religion as part of the curriculum. It also changed the procedure for student promotion, considered so far by PP and several social stakeholders involved in educational policies to be very flexible and tolerant to students, and it was believed to produce indiscipline, lack of respect for teachers and to give little value to effort.

LOCE did not come into force, since the first year in which it had to be applied, academic year 2004-05, coincided with the arrival of socialist José Luis Rodríguez Zapatero's Government. With this Government, the Organic Law on Education (LOE) was enacted in 2006. Since PSOE did not have an absolute majority in the Spanish Parliament, it needed the support of other parties, which was found in left-wing parties and in Catalan, Basque, Canarian and Galician nationalist parties.

However, LOE originated a heated public debate, since Religion (Catholic or other) was not considered a "gradable" course and "Education for Citizenship" was included as a compulsory subject, whose content was considered an ideological indoctrination of progressive values by conservative stakeholders and by the Spanish Episcopal Conference.

This Law did not alter any agreements with private schools, as these matters remained in the ACs hands, but strengthened them instead, as the Central State started financing teachers' salaries by transferring funds to ACs.

A new change in the State's framework occurred after the powers were transferred to all ACs in 2001. This means that LOE equally affected all ACs. For the ACs which had received their powers in the 1980s, LOE was an opportunity to confirm or not their educational model, rethink old public problems in the regional public agenda, or introduce new issues. For ACs which had received their powers at the turn of the century, LOE was an opportunity to develop their own educational model, beyond what they had inherited from the Central State.

Schools' management autonomy became a key point around which the different stakeholders took sides also in the regions chosen for this study. As mentioned above (Bolívar, 2008; Madera, Martin and Pérez, 2013), the Central State's political subsystem did not solve this issue before, as these powers were transferred to the regions in 2000. The problem stream had not successfully defined neither high school's degree of management autonomy nor the teaching method they should implement. Social stakeholders that could be involved in this matter, such as parents associations and 
teachers' unions, were not given sufficient priority and the social demand for a better education was not linked to the autonomy of schools. For decades, these demands called for a quantitative increase in the resources spent on education: more teachers, more schools, more scholarships and grants, more educational materials (Bonal,1998). This issue had never been given priority in the political stream before, so the window of opportunity had never opened for the autonomy in the management of schools. In both cases, the solution was sought in agreements with private schools.

Among all the ACs we can identify the Region of Madrid, the Basque Country and Andalusia as particularly significant due to their clear definition of their own models. Each one of them responds to different circumstances in terms of ruling parties and types of majorities at regional level, networks of social stakeholders, moment of power transfer and financing.

\section{A linguistic Issue: the Basque Country Case}

The Autonomous Community of the Basque Country received powers in non-university education essentially in 1980. In the early years of the autonomous implementation of the powers in secondary education, the Basque Government found the main difficulties in managing the administration's material resources on the one hand and the staff on the other hand. Both issues were handled by creating structures and rules for operating the Basque Government and administration.

The initial situation inherited from the Central State in the Basque Country regarding secondary education had some peculiarities when compared to the rest of Spain. The service was provided by means of two models, public and private, with a 50-50 student share.

In the public model, involving direct management and public ownership, high schools were managed according to a very centralized, hierarchical and bureaucratic scheme.

The private model consisted of a group schools which were privately owned and managed, but divided into two different types. The first type comprised private schools belonging to Catholic orders. The second type were schools set up by parents of students, cooperatives called "Ikastolas". These parent cooperatives were formed to give a different education to the public education content of the Franco Regime and the Law of 1970, and were linked, in many cases, to Basque nationalist ideology.

LODE in 1985 meant an opportunity in the problem stream for the Basque Autonomous Community, and LOGSE in 1990 consolidated this opportunity.

The political stream in the autonomous political subsystem picked up momentum in the Basque election of 1987. A Government coalition between PNV (Basque nationalist) and PSE (PSOE's Basque section) was created and this 
coalition assigned the Regional Ministry of Education to PSE. Then the main characteristics of the current Basque educational model were defined, based on political agreements between Basque nationalists and Socialists (Dávila Balsera, 2004).

The foundations of this model consolidated after the regional election in 1991 and then with different Government coalitions, as PSE remained a minority Government partner up to 1998, holding the Regional Ministry of Education until then. Later, this Regional Ministry was taken over by Eusko Alkartasuna $(\text { EA) })^{6}$ until 2009.

In short, the main features of the Basque case were laid from 1987 to 1991. These remain today, although they have been challenged. Practically all private schools, whether Ikastolas or other types of private schools, were contracted as external providers of the public system, and have that same status today. There are hardly any private education providers without an agreement, and the ratio of students in private and public education remains stable at around $50 \%$.

Secondary education schools, whether directly managed or outsourced, must offer three teaching models, according to the language in which courses are taught. The choice between one and the other is up to the parents. These three models are called A, B and D:

A. In Spanish language, except for the Basque language course.

B. Mixed, with prevalence of the Basque language.

D. In Basque language, except for the Spanish language course.

Schools have some autonomy to offer one or another model, and are responsible for providing training to their faculty in Basque language for them to be able to teach their courses in either language, considering that teachers who did not speak Spanish were exceptional to start with. This autonomy of centers to meet demand has also been used by their managers to introduce quality tools or standardizing procedures in some cases.

The main public issue found in the Basque educational system is the language: the use of Basque or Spanish in teaching. The evolution of demand for this model has led to the offer of model A being limited to some urban areas of province capitals. The parents' demand is focused on models B and D. However, the possibility to study following the model A exists.

In 2006, after LOE was released, the Basque Government at that time consisted of a coalition between PNV, EA and EB (Ezker Batua) ${ }^{7}$, and the Regional Ministry of Education was held by EA. The new law was used to challenge the continuity of the model in the government's agenda. The reason was that,

6 A nationalist political party which split from PNV in 1985, and which could be considered more progressive and secular than PNV.

7 Section Basque United Left, political organization to the left of PSOE. 
although models $B$ and $D$ prevailed in secondary education, the use of the Basque language in society was considered insufficient, particularly in the three province capitals and areas such as the industrial zone near Bilbao and the South of the province of Alava. As an alternative choice, these Basque nationalists proposed the Catalan model, known as »immersion«, however this option was finally dismissed and the three-way model remained.

After the 2009 election there was a change in the Government of the Basque Country, and PSE formed a Government with the parliamentary support of PP. For PSE, as for EA, education is a matter of priority in their party's agenda.

Considering that PSE had been a protagonist in the design and implementation of the original educational model agreed with PNV, we could understand that they would be reluctant to change it. However, the Socialist Basque Government introduced changes to the model, although it did not approach it as a reformulation of the policy, but as a mere addition to the traditional three-way model. They did not reformulate the public issue that gave rise to the model, just introduced a specific program, along with others, as an upgrade or update of the same model. It was therefore presented as an incremental solution.

The update of the model revealed that it had weaknesses, produced over time, such as the use of new technologies in education and training in English. For this last weakness, the Basque Ministry of Education presented a trilingual program, so instead of dividing each model into two languages, they were divided into three: Spanish, Basque and English. Although the teaching time ratios for each language were initially discussed within the public agenda, at the end the program allowed public and outsourced private high schools to decide whether to introduce English in each of the models that they were already offering, leaving at least $20 \%$ to each of the three languages if they did. In short, the decision to introduce or not the program remained in the hands of high schools, as well as the programs for the use of new technologies. High schools that applied this program received economic incentives, such as English training for teachers, material resources and grants for activities in English.

At the end of the term of the PSE Government in 2012, the output of this program was to blur the original three-way model, and its implementation was limited.

We may consider the Basque case to be an attempt to change the policy. The consensus on the educational model which originated for the first time since 1987 created a stable network with stakeholders specialized in this policy. These stakeholders include trade unions, both nation-wide left-wing unions and Basque nationalist unions; parents' associations, which are usually moderate Basque nationalist, or employer associations, also close to nationalism. All of those make up a network which is rather favorable to Basque nationa- 
lism and which prioritizes the Basque language as the main issue of secondary education in the Basque country, keeping the A-B-D model as a stable solution at least until 2009, as opposed to the Central State where the model is constantly changed.

Challenging the policy between 2009 and 2012 by the Basque Socialists in the regional government was an attempt to change on a large scale, but the result was the restoration of balance. It should be noted that the trilingual program gave rise to protests and social demonstrations led by social organizations with a nationalist ideology, such as trade unions and parents' and students' associations.

We can also understand that the Central State caused with LOE the event that drove the problem stream (Zahariadis, 1999) to the Basque Autonomous Community. Additionally, studies and expert opinions push the policy stream in favor of promoting English studies, even for teaching other courses, giving credibility to the option adopted by the Socialist Government in the Basque country in 2009. Finally, the political stream shows that the ideology of the ruling party (Zahariadis, 1999) is critical of the selection of alternatives, both in the Socialist Government and in the previous nationalist Governments and also in the subsequent Socialist Government.

\section{The Search for a Direct, Public and Egalitarian System: the Case of Andalusia}

The region of Andalusia received basic powers in non-university education in 1982 and 1984 shortly before the Central Government enacted LODE in 1985. From then on, the main objective of successive heads of the Regional Ministry of Education was adapting material and human resources transferred according to such Law, but taking into account that most of these resources were in public hands, i.e. that the possibilities for Andalusia to get outsourcing agreements with private high schools were limited by the low amount of these when compared to other ACs.

The main objective of the Autonomous Community of Andalusia from 1985 to 2006 was to extend the provision of educational services. Firstly, by handling the increase of students in the 1980s and, secondly, by extending the age of obligatory education and increasing the services to students with disabilities or diversity in the 1990s, implementing LOGSE. Thus, the main objective was quantitative: building more public schools and increasing staff and resources.

It should be noted that the Andalusian Government, since its creation in 1982 until now, has always been ruled by the Andalusian section of PSOE (PSOEA) ${ }^{8}$. This situation has supported continuity in policy-making, with stability in

8 Since 2012, the government of Andalusia is a coalition with political party Izquierda Unida for the first time, as the Socialist Party did not reach an absolute majority in the Andalusian Parliament - this situation had only happened previously from 1994 to 1996. 
the identification of public issues and their solutions, as well as an almost absolute control of the Government agenda by PSOE-A. The definition of objectives has mirrored PSOE-A's prevailing values and ideology. Among them, in the period before 2006, Andalusian leaders preferred direct public management to providing the service through agreements with private schools, particularly Catholic, as a way of securing the right to free choice of values by parents, beyond the attention to the temporary increase of demand posed by LODE in 1985.

To comply with the legal framework established by the Central State, the Andalusian Government reached an agreement with private schools. Thus, an $80 / 20$ ratio was established between directly managed schools and schools whose management was outsourced. This balance remained until 2006. However, it should be noted that the public sector was responsible for reaching the most deprived areas, even marginal areas, and that LOGSE provided for additional resources in these areas.

In addition, the Regional Ministry of Education kept control over directly managed schools, by keeping an ongoing contact with principals, transferring economic, material and human resources, and through the presence of education inspectors in schools. This did not eliminate the role of School Councils, although most parents' associations [AMPAS] in Andalusian public schools share left-wing values and strategic objectives. No unions representing teachers in the public sector seem to have discussed the fundamentals of the Andalusian educational model, and the control of public schools by the Regional Ministry, so the School Councils have not been forums to claim for specific educational projects for their school.

In brief, Andalusia has set up an educational model where direct management, administrative centralization and control of secondary education schools prevail, and where students are preferably selected based on their place of residence (Merchán Iglesias, 2012).

The key elements of this model remained the same after LOE was enacted in 2006. However, the Andalusian Government took the opportunity to redefine its policy for secondary education. Both the Andalusian Government and the most relevant stakeholders, such as parents' associations, trade unions and political parties, agreed that Andalusia faced two main public issues regarding secondary education in 2006: high drop-out rates and students' school failure.

High drop-out rates is a phenomenon that took place in Andalusia prior to the transfer of powers, because parents in rural areas traditionally required their children to start working at an early age. From the 1980s to 2008, the school drop-out phenomenon began to be connected to the fact that young people found it easy to find a job in the building industry, quitting the educational system without ending their period of obligatory secondary education. 
To solve these issues, the Andalusian Government redesigned its educational policy through a regional law enacted in 2007: the Law on Education for Andalusia (LEA) of 2007. LEA was an initiative of the Andalusian Government, which included in its draft before it was submitted to the Andalusian Parliament the standpoint of majority trade unions then, UGT and CC.OO., with a similar ideology to PSOE-A, through a roundtable agreement ${ }^{9}$. Policy-makers also listened to the School Council of Andalusia, where associations of students, parents and private school employers were represented, as well as the Association of Principals of secondary education public schools. Within each sector, PSOE-A gave greater importance to closer organizations, for example, the Association of Teacher Cooperatives received more attention than "Catholic Schools", a conservative organization.

The participation of the social stakeholders in the area of secondary education also happened in the Parliamentary process. In the Parliamentary Commission almost all stakeholders appeared, but without a vote. The Andalusian Parliament finally passed LEA with the votes of PSOE-A, which had the absolute majority and IU, which was not ruling with PSOE-A at that time; however, $P P$ voted against.

Although it may be considered that LEA marks a starting point in Andalusian education, programs developed from LEA on to solve public issues in compulsory secondary education may be considered incremental as opposed to the situation before 2006 .

Regional programs increasing and intensifying the strategies and the means set out at that time by LOGSE regarding school failure: personalized actions for students with disabilities, with extra support classes; more availability of curricular pathways, or promoting the use of new technologies as a means to integrate youth in the educational system, for instance. Additionally, the Andalusian Government developed and implemented a new specific program, "Scholarship 6000", whereby the Administration paid 600 euros per month during school months to students who lived in low-income areas and whose families required them to enter the job market.

It should also be noted that LEA struck the balance of outsourced private schools, allowing a 4 year extension of existing agreements, but stating that in the event the demand of students in a certain area decreased, the Government would not renew the service agreement, moving students to the nearest public school or choosing a private school outside the public sector. In 2012, this led to a 20-18\% drop in the share of outsourced private schools.

In brief, the Andalusian Government has used the LOE framework to take an incremental step in its educational model (Lindblom, 1979), although it has

9 It is a corporate body of negotiation for the working conditions of staff. Currently there is a table for teachers of the public sector and another one for the teachers of the outsourced private sector. 
opened a reformulation process for all educational public policies by developing a regional Law. The end result was a reinforcement of the policy made before, considering that education was a priority for PSOE-A.

The policy stream came to Andalusia from the Central State in 2006, coinciding with the political stream in the regional political subsystem. Thus, both streams opened the window of opportunity for the Andalusian Government, which used them to change the objectives of its policy. However, this did not mean a review or a change in its management model for secondary education. Among other reasons, this was due to the fact that, since the powers were transferred, a stakeholders' network was formed following this policy, which finally became an advocacy coalition around PSOE-A (Sabatier \& Jenkins-Smith, 1999). The stakeholders' coalition, including unions, parents' associations, the Association of Secondary School Principals, education inspectors, etc. promoted LOA, and it was not in their interest to change the management model, although this was one of the objectives of LOE.

\section{A Process of Privatization: the Region of Madrid}

In the case of the Region of Madrid, its starting point was clearly different from the other two ACs, since it received powers in Education between 1999 and 2000. This means that the entire development and implementation of the Central State's framework laws, such as LODE and LOGSE, corresponded to the Central State's Ministry of Education until 2000 in the territory of the Region of Madrid, which defined a model for secondary education that we may define as neutral, as it did not define any specific aspects for Madrid, nor for any other Autonomous Community.

Thus, in the case of the Region of Madrid, the educational model could be defined specifically since 2000, but at first it took on the model it had received without challenging the previous situation. We must take into account that Madrid's Regional Government has been held by PP since 1995 until now with an absolute majority in the Regional Parliament.

In the early years, the main concern of the educational authorities of the Region of Madrid seemed to be the change that the Central Government intended to make regarding the general educational framework with LOCE, the law which did not come into force in 2004. This law would have provided the chance to define a model that would explicitly develop PP's principles and values in the ACs. These principles aim at giving more weight to outsourced private schools and at including the Catholic religion as a "gradable" course, which is the Central State's jurisdiction. However, as LOCE did not enter into force, the opportunity to define the model for secondary education of the Region of Madrid with these principles was postponed until 2006, with LOE, but adapted to the particular circumstances of this territory. In fact, this adaptation already began in 2003, with the new regional President, Esperanza Aguirгe. 
Until 2003, new developed areas where new schools had to be built became widespread. Outsourced private schools were allowed to be built in these areas, but with a lower density than public schools. In practice, this allowed for some room for choice in the newly developed areas. However, this period coincided with a huge real estate expansion and the development of many new urban areas, so Madrid experienced a heavy population growth, from 5 to 6,5 million from 1995 to 2012.

From 2003, the regional Government began to sign outsourcing agreements for new urban development areas that included the assignment of the land covered by the secondary school for 75 years. This land was reserved to build public educational facilities and was owned by the Region of Madrid. In return, private investors undertook to build the schools, and the Government of Madrid to not allow other public or outsourced private school in the area, so there was no competition ${ }^{10}$. Currently, the capacity of outsourced private schools is $50 \%$ versus directly managed high schools.

In the case of the Region of Madrid, the salary of a teacher working for private outsourced education is lower than the salary of teachers of public sector. If we add to this the immediate savings from the construction of buildings, it means that the objective of saving costs has been met, and allows us to identify that Madrid's political leaders have defined a problem of costs generated by the provision of educational services. However, this practice ended in 2009, as there were no private investors willing to partner up with the public sector under such collaboration agreement.

Other changes in the Regional educational policy were presented as partial programs, and not as a general policy plan. However, if we analyze them as a whole we can see that they have a purpose and common values.

The most outstanding secondary education programs have been: the program of bilingualism, English and Spanish, and the program for educational excellence. Both seek to improve access of students in secondary education to the job market. This implies the definition of a public problem involving the students' misalignment with the needs of companies. For this purpose it is essential to introduce stricter criteria for student promotion, the opposite to what LOGSE set forth and in line with LOCE.

However, these programs' performance is being discussed by social stakeholders who oppose this policy, because they state that these programs have suffered budgetary cuts with the economic crisis and that their results are limited.

In short, we can understand Madrid's secondary education model is characterized by a market-driven approach, both in the manner the service is provided and in the type of students seeks it to lead to graduation, and it fosters

10 We may considerer it to be a kind of PFI, Private Finance Initiative. 
competition between students. It is a model that seeks economic efficiency over the integration of educational stakeholders, and the role of unions, associations of parents and students, and employers is small in the political agenda (Antón, 2009).

However, this model tends to give a certain degree of management autonomy to directly managed schools. The school managerial teams may choose to adopt programs such as bilingualism or excellence, even if this means losing the resources involved. They can also choose to offer certain optional courses, if they identify a specific demand beyond their area of coverage. In short, the relationship with the Regional Ministry of Education gives them some room to make decisions.

If we analyze the case of the Region of Madrid from the point of view of the multiple streams in Zahariadis' version (1999), we see that the problem stream was driven by LOE in 2006, and it was perceived as an opportunity for the Regional Government, which coincided with a policy stream, as it was an expert knowledge linked to some right-wing think tanks and to other experts related to the previous Law on the Quality of Education (LOCE). These two streams also coincided with the third, the political stream, since the solution adopted for secondary education includes values and beliefs which are part of PP's identity in Madrid.

\section{Conclusions}

In short, if we look back at the questions we asked initially regarding these three ACs: the answer to the first one - "Why have they defined different models if the State's general framework is the same?" - is that they have done so because they respond to very different social environments, which makes them develop different answers to different public problems. The window of opportunities arising from the current problems (Zahariadis, 1999) is specific for each Autonomous Community, although it can be opened due to the changes in the state legislation. Therefore, the autonomous jurisdiction of secondary education has fulfilled its aim to adapt the policies to social environments and the answer to the question "Do they adapt to different situations of each Autonomous Community?" is affirmative, as well.

The answer to the question "What criteria do they follow to set their policies?" has already been answered; the criteria are the ideology of the ruling parties, which enables a clearer identification with the decisions of voters, but it also implies greater tensions and disputes in education policies, since the lack of agreement between parties makes the policies to be interrupted with the changes of the party in power, as it also occurs in the Central State. It are the ruling parties which influence the policy flows most and identify the opening of the window (Zahariadis, 1999). 
Do they integrate into the processes of defining the problems and objectives for social stakeholders? The answer is that social players participate in the school councils of ACs formally and as consultants. Nevertheless, the social sectors that are ideologically more related to the ruling parties have more informal relations and a greater influence on the policies of the ACs involved in the research. This aspect represents a line of research to be developed in the future.

Eliseo López Sánchez, PhD, Assistant Professor at the Faculty of Political Science and Sociology of the UCM [Facultad de CCPP y Sociología Universidad Complutense de Madrid]. He holds a Master's Degree in Public Administration from Instituto Universitario Ortega y Gasset (IUOG) - National Institute of Public Administration (INAP), he teaches various courses related to public policy, governance and political systems. He is a researcher in several projects on local and regional public policy and intergovernmental relations, author of different publications, book chapters mainly. Previously, he worked as a coordinator of research teams in the Third Sector as a Senior Consultant in the Private Sector.

Esther del Campo, PhD, Professor of Political Science and Public Administration at Instituto Complutense de Estudios Internacionales of Universidad Complutense de Madrid. She is the Head of the PhD program "Government and Public Administration" at the Ortega-Marañón Foundation. Her main research interests and publications include Comparative Politics, Governance and Institutional Reform, Decentralization and Political Participation. Currently she is the Director of Complutense Institute for International Studies (ICEI). 
Patterns, Trends and Policy Processes in Spanish Secondary Education: Multiple Streams in a Multilevel Context

\section{References}

Antón, A. (2009). Políticas educativas ante la crisis. Madrid: Fundación $1^{\circ}$ de mayo.

Beltrán LLavador, J., Hernández Dobon, F., \& y Montané López, A. (2008). Tradición y modernidad en las políticas educativas en España: una revisión de las últimas décadas. Revista Iberoamericana de Educación, 48, 53-71.

Bolívar, A. (2008). La autonomía de centros educativos en España: entre declaraciones discursivas y prácticas sobrerreguladas. In A. García Albaladejo (Ed.), La autonomía de los centros escolares (pp. 29-64).Madrid: MEPSYD.

Bonal, X. (2011). Descentralización de la política educativa: balance y perspectivas de futuro. Ponencia presentada en el I Seminario sobre educación y políticas educativas en España, Madrid 15-17 November 2011.

Bonal, X. (1998). La política educativa: dimensiones de un proceso de transformación. In R. Gomà \& J. Subirats (Eds.), Políticas Públicas en España (pp. 153-175). Ariel. Barcelona.

Bonal, X. (2002). El balance público-privado en el sistema de enseñanza español: evolución y efectos sobre las desigualdades educativas. Educar, 29, 11-29.

Consejo Escolar de Andalucía. (2008). Informe sobre el estado y situación del sistema educativo de Andalucía 2005-06, 2006-07. Sevilla: Consejería de Educación de Andalucía.

Consejo Escolar de Andalucía. (2010). Informe sobre el estado y situación del sistema educativo de Andalucía 2007-08, 2008-09. Sevilla: Consejería de Educación de Andalucía.

Consejo Escolar de la Comunidad de Madrid. (2008). Informe sobre la situación de la Enseñanza no Universitaria en la Comunidad de Madrid Curso 2005-2006. Madrid: Consejería de Educación, Juventud y Deporte.

Consejo Escolar de la Comunidad de Madrid. (2009). Informe 2009 sobre la situación de la Enseñanza no Universitaria en la Comunidad de Madrid Curso 20072008. Madrid: Consejería de Educación, Juventud y Deporte.

Consejo Escolar de la Comunidad de Madrid. (2012). Informe 2012 sobre la situación de la Enseñanza no Universitaria en la Comunidad de Madrid. Madrid: Consejería de Educación, Juventud y Deporte.

Consejo Escolar de Euskadi. (2010). Informe sobre la situación de la enseñanza en Euskadi, 2006-2008. Vitoria-Gasteiz: Consejo Escolar de Euskadi.

Consejo Escolar de Euskadi. (2012). Informe sobre la situación de la enseñanza en Euskadi, 2008-2010. Vitoria-Gasteiz: Consejo Escolar de Euskadi.

Dávila Balsera, P. (2004). Las políticas educativas en el País Vasco durante el siglo $X X$. Madrid: Biblioteca Nueva.

Kingdon, J.W. (1984). Agendas, alternatives and public policies. Glenview, IL: Scott, Foresmand and Company.

Lindblom, Ch. (1979). Still Muddling, not yet through. Public Administration Review, 39(6), 517-526.

Madera, E., Martín, P., \& Pérez, L. (2013). Políticas Públicas de las Comunidades Autónomas. Descentralización y Servicios de Bienestar. In J. Ferri (Ed.), Política y Gobierno en el Estado autonómico (pp. 269-310). Valencia: Tirant lo Blanc.

Maguire, Loreal L. (2008). Developing Distance Education Policy Within a State System of Higher Education: the Faculty Perspective. Ann Arbor: MIC. 
Merchán Iglesias, J. (2012). La introducción en España de la política educativa basada en la gestión empresarial de la escuela: el caso de Andalucía. Education Policy Analysis Archives, 20, 1-24.

Sabatier, P. A. \& Jenkins-Smith, H. C. (1999). The Advocacy Coalition Framework: An Assesment. In P. Sabatier (Ed.), Theories of the policy process (pp.117-166). Boulder, Co.: Westview Press.

Zahariadis, N. (1999) "Ambiguity, Time and Multiple Streams. In P. Sabatier (Ed.), Theories of the policy process (pp. 73-94). Boulder, Co. : Westview Press.

Zachariadis, N. (2003) Ambiguity and Choice in Public Policy: Political manipulation in Democratic Societies. Washington, D.C.:Georgetown University Press.

Zachariadis, N. (2007). The multiple Streams Framework: Structure, Limitations and Prospects. In P. Sabatier (Ed.), Theories of the policy process (2nd ed) (pp. 65-92). Boulder, Co.: Westview Press.

Law 14/1970, of 4 August, General on Education and Financing of the Educational Reform, as amended by Law 30/1976, of 2 August. (B.O.E. [Spanish Official Gazette] of 6 August, 1970, as amended in B.O.E. of 3 August, 1976). From: www.cyberpadres.com/legisla/boe_14.pdf

Law 1/1993, of 19 February, on the Basque Public Education (B.O.P.V. [Official Gazette of the Basque Country] of 25 February, 1993). From: http://noticias. juridicas.com/base_datos/CCAA/pv-l1-1993.html

Law 2/1993, of 19 February, on Teaching Bodies for Non-University Education in the Autonomous Community of the Basque Country (B.O.P.V. of 25 February, 1993). From: http://noticias.juridicas.com/base_datos/CCAA/pv-l2-1993.html

Law 3/2008, of 13 June, on the second amendment to the La won the Basque Public Education (B.O.P.V. of 23 June, 2008). From: http://noticias.juridicas. com/base_datos/CCAA/pv-l3-2008.html

Law 17/2007, of 10 December, on the Education in Andalusia (B.O.J.A. [Official Gazette of the Andalusian Government] of 26 December). From: http://www. lexureditorial.com/boe/0801/01184.htm

Organic Law 8/1985, of 3 July, Governing the Right to Education (B.O.E. of 4 July, 1985), in: http://noticias.juridicas.com/base_datos/Admin/lo8-1985.html

Organic Law 1/1990, of 3 October, General Regulation of the Educational System (B.O.E. of 4 October, 1990). From: http://www.uclm.es/profesorado/ ricardo/LOGSE2.htm

Organic Law 9/1995, of 20 November, on Participation, Asessment and Management of Teaching Centers (B.O.E. of 21 November, 1995). From: http:// noticias.juridicas.com/base_datos/Derogadas/r1-lo9-1995.t4.html

Organic Law 10/2002, of 23 December, on the Quality of Education (B.O.E. of 24 December, 2002). From: www.boe.es/boe/dias/2002/12/24/pdfs/A4518845220.pdf 


\section{Vzorci, trendi in procesi oblikovanja politike v španskem srednješolskem izobraževanju: številni tokovi na več ravneh}

Ključne besede: izobraževalni sistem, javno srednje šolstvo, neposredno upravljanje, oddajanje del, krajevne pristojnosti, vlada na več ravneh, Španija

Raziskava o srednješolski izobraževalni politiki temelji na intervjujih s pripravljavci politike in številnimi drugimi deležniki iz treh avtonomnih pokrajin in državne vlade. Avtorja sta tudi upoštevala vse dostopno literaturo o javni srednješolski izobrazbi v Španiji in druga zakonska besedila ter medijske objave o dogajanju v pokrajinah. Kot teoretični okvir za pristop k študiji sta izbrala pristop številnih tokov ali oken priložnosti, ki ga je razvil Kingdon (1984) in kasneje uporabil Zahariadis $(1999,2003,2007)$. Ta pristop prepoznava tri tokove - tok problemov, tok javnih politik in tok politične volje - ki se v neki časovni točki lahko združujejo, tako da ustvarijo t. i. okna priložnosti ter omogočajo, da politični akterji tematike, za katere se zavzemajo, vključujejo na dnevni red vlade.

Vprašanja v raziskavi so bila naslednja: Zakaj so bili modeli pokrajin opredeljeni drugače, čeprav delujejo v enotnem državnem okviru? Kakšni kriteriji so bili upoštevani pri pripravi politik izobraževanja? Ali se prilagajajo različnim okoliščinam vsake avtonomne pokrajine? Ali v procese prepoznavanja problemov in ciljev vključujejo deležnike?

Članek opisuje prvotno stanje izobraževalne politike na državni ravni, kot izhodišče za kasnejša ključna področja političnega soočenja, medtem ko se je pristojnost za srednješolsko izobraževanje kasneje prenašala z državne na krajevno pristojnost - na raven pokrajine.

Članek je razčlenjen na štiri glavne dele in sklepe. Prvi del obravnava španski izobraževalni sistem in prikazuje tako pravne spremembe kot tudi institucionalno inercijo, do katere je prišlo v času izbranega obdobja. Drugi, tretji in četrti deli opisujejo in analizirajo srednješolske izobraževalne modele treh izbranih španskih avtonomnih pokrajin in sicer: Baskije, Andaluzije in Madridske regije.

Avtorja v članku predstavita odgovore na vprašanja, ki sta si jih glede omenjenih treh avtonomnih skupnosti zastavila v raziskavi. Na vprašanje "Zakaj so bili modeli opredeljeni drugače, čeprav delujejo v enotnem državnem okviru?« je odgovor naslednji: »Ker ustrezajo zelo drugačnim družbenim okoljem, zaradi česar razvijejo zelo drugačne rešitve na drugačne javne probleme«. Okno priložnosti, ki izhaja iz trenutnih problemov (Zahariadis, 1999), je specifično za 
vsako izmed izbranih pokrajin in ga je mogoče odpreti s spremembami zakonske ureditve. Prav zato je bil s krajevno pristojnostjo srednješolskega izobraževanja izpolnjen cilj prilagoditve politike družbenim okoljem. Torej je pritrdilen tudi odgovor na vprašanje: "Ali se modeli izobraževanja prilagajajo različnim okoliščinam vsake pokrajine?«.

Vprašanje »Kakšni kriteriji so upoštevani pri pripravi politik izobraževanja?« je tako že dobilo svoj odgovor - kriteriji so namreč kar ideologija vladajočih strank. Slednje sicer omogoča jasnejše istovetenje z odločitvami volivcev, vendar pa obenem povzroča tudi večje napetosti in spore glede izobraževalnih politik, ker različna stališča posameznih strank pogosto povzročajo, da se ob spremembi vladajoče stranke politike prekinejo, kar se dogaja tudi na državni ravni. Na razvoj politik in opredelitev oken priložnosti namreč najbolj vplivajo prav odločitve vladajoče stranke (Zahariadis, 1999).

"Ali v procese prepoznavanja problemov in ciljev vključujejo deležnike?» Odgovor na to vprašanje se glasi: družbeni akterji sodelujejo v šolskih odborih avtonomnih skupnosti formalno in kot svetovalci. Kljub temu imajo družbeni sektorji, ki so ideološko bolj povezani z vladajočimi strankami, več neformalnih povezav in večji vpliv na politike izbranih pokrajin. 